\title{
Reduction of Heavy Metals from Waste Water by Wetland
}

\author{
Omprakash Sahu \\ Department of Chemical Engineering, KIOT Wollo University, Kombolcha, Ethiopia \\ Tel: +251933520653 \\ E-mail address: ops0121@gmail.com
}

\begin{abstract}
Constructed wetlands are artificial wastewater treatment systems consisting of shallow ponds or channels which have been planted with aquatic plants, and which rely upon natural microbial, biological, physical and chemical processes to treat wastewater. They typically have impervious clay or synthetic liners, and engineered structures to control the flow direction, liquid detention time and water level. Depending on the type of system, they may or may not contain an inert porous media such as rock, gravel or sand. Constructed wetlands have been used to treat a variety of wastewaters including urban runoff; municipal, industrial, agricultural and acid mine drainage. In this regard's an attempted has been made to reduce the heavy metal present in waste water.
\end{abstract}

Keywords: Biomass; Contaminates; Plant; Metal ions; Natural treatment

\section{INTRODUCTION}

Constructed wetlands are essentially inspired by natural processes in naturally occurring wetlands. Natural wetlands marshes, swamps, bogs, everglades are highly productive ecosystems storing large volumes of water, recalculating nutrients, providing habitats that support a diverse population of plants and animals, and removing pollutants from the water (Carvalho and Martin, 2011). Wetlands, under natural conditions, are capable of providing significant pollutant removal from influent streams of impaired waters including storm water, municipal and industrial wastewater, landfill leachate, and urban runoff (Rasit, 2006). Treatment in wetlands occurs as a result of settling of suspended particles, oxidation of organic matter, and metabolic activity by indigenous microorganisms, photolysis, and uptake of nutrients by plants growing within the wetlands (Smith et al., 2005). As long as the wetland is not overloaded, dried out, or subjected to extended cold periods, effluent quality can be expected to be suitable for most non-potable uses (Hao and Loosdrecht, 2004). Natural wetlands have long been used for discharge of treated wastewater effluents primarily as a disposal measure, but also as a means of reducing nitrogen, phosphorus, heavy metal and pathogen concentrations in the effluent. However, intentional and planned use of constructed wetlands for wastewater treatment is relatively new (Fennessy et al., 2002).

Heavy metals are usually found in industrial wastewater and mine drainages. However insignificant quantities may be detected in municipal wastewaters (Vymazal, 2005). The main heavy metals associated with wastewater and produced by mines and industries are 
chromium, iron, mercury, copper, lead, cadmium and zinc (Thullen et al., 2005). These heavy metals are removed from constructed wetland system by a variety of methods including filtration and sedimentation, adsorption, uptake into plant material and precipitation by geochemical processes (Stottmeister et al., 2003). Removal rates of heavy metals by constructed wetland have been reported to be up to $100 \%$ (Romero et al., 2011). Other possible removal rates by a $\mathrm{CW}$ as reported by Sheoran and Sheoran (2006) are 75-99 \% cadmium, $26 \%$ lead, $76 \%$ silver, and $67 \%$ for zinc, while COD, BOD and TSS were removed at a rate between 75 and $80 \%$. Metals were demonstrated to accumulate in the leaves, shoots, rhizomes with roots and lateral roots having the highest content, while the lowest concentrations were found within the shoots (Zachritz et al., 2006). This was demonstrated by sampling the above mentioned parts of the plant and concentrations of the metals were determined using spectrophotometric methods. In surface flow systems used to treat mine drainage, $\mathrm{Fe}(\mathrm{II})$ is oxidized to $\mathrm{Fe}(\mathrm{III})$ by abiotic and microbial oxidation.

For successful commercial applications, constructed wetland systems should have an ability to remove pathogens from wastewater. Research over the past years indicates that wetland systems have an ability to reduce pathogens with varying but significant degrees of effectiveness (Karim et al., 2004). Microbial water quality improvements using wetlands have been reported, with some studies reporting up to $57 \%$ reduction of total coliforms, $62 \%$ of fecal coliforms, $98 \%$ reduction of most species of Giardia, $87 \%$ of most Cryptosriduim spp. And $38 \%$ of coliphage (Stottmeister et al., 2003; Karim et al., 2004). Human pathogenic viruses were also found to be removed from wetland systems (Juwarkar et al., 1995). Viruses associated with large particles leave water column and settle into the bottom sediments while some are adsorbed on colloidal particles tend to stay suspended in water for longer time (Karim et al., 2004).

Constructed wetlands have been classified by the literature and practitioners into two types. Free water surface (FWS) wetlands (also known as surface flow wetlands) closely resemble natural wetlands in appearance because they contain aquatic plants that are rooted in a soil layer on the bottom of the wetland and water flows through the leaves and stems of plants (Carleton et al., 2011). Vegetated sub-merged bed (VSB) systems (also known as subsurface flow wetlands) do not resemble natural wetlands because they have no standing water (Allen et al., 2012). They contain a bed of media (such as crushed rock, small stones, gravel, sand or soil) which has been planted with aquatic plants. When properly designed and operated, wastewater stays beneath the surface of the media, flows in contact with the roots and rhizomes of the plants, and is not visible or available to wildlife (Malmaeus and Hakanson, 2003).

Application of constructed wetland technology for commercial wastewater treatment could signify a step towards "green technology" as this technology is environ-mental friendly and sustainable (Bailey, 1976). It eliminates the use of chemical such as those currently used in conventional wastewater treatment as well as minimizes the amount of carbon dioxide released into the atmosphere. Carbon dioxide released through microbial decomposition is reused by macrophytes in the process of photosynthesis (Eriksson, 2011). It is recommended that since this technology is relatively new in industrial and municipal applications, there is a need for continuous research and development to test the viability of this system under various conditions, including applicability for different types of waste-waters, effectiveness under different climatic conditions and the use of different materials and plants. The performance of existing constructed wetlands should be carefully monitored and additional research is required to optimize design and minimize construction cost. Local governments as well as international organizations involved in water and wastewater sector should promote this technology by building local capacity and scaling up its application. 
The main aim of the work is to study the reduction of heavy metal present in the waste water as well as pathogen which affect the life. An attempt has also been focus on effect of flow rate retention time and temperature.

\section{MATERIAL AND METHODS}

\section{1. Material}

The synethic water was generated in lab with chemical. The chemicals and reagents used were of A. R. grade and were obtained from E. Merck, India.

\section{2. Methods}

The most critical component of constructed wetlands is land. Because of the relatively large surface area necessary for a given flow, use of constructed wetlands is generally limited to smaller communities, usually down to single-family or single-building settings. The land is shaped into basins, commonly (but not always) lined with impermeable membranes and sloped to provide a gentle flow from the inlet to the outlet of the treatment system (Baker, 2008). A gravel lining is built above the liner and it can vary in thickness from a minimal root zone to varying depths that might extend to above the water line. The flow diagram is shown in Fig 1. In extremely hot and dry climates, a gravel or sand bed can help minimize evaporative loss of water. A mix of aquatic plant materials (cattails, bulrushes, reeds, etc.) growing either hydroponically or in a gravel substratum provide the media through which polluted water is filtered and biologically treated (Salih, 2013).

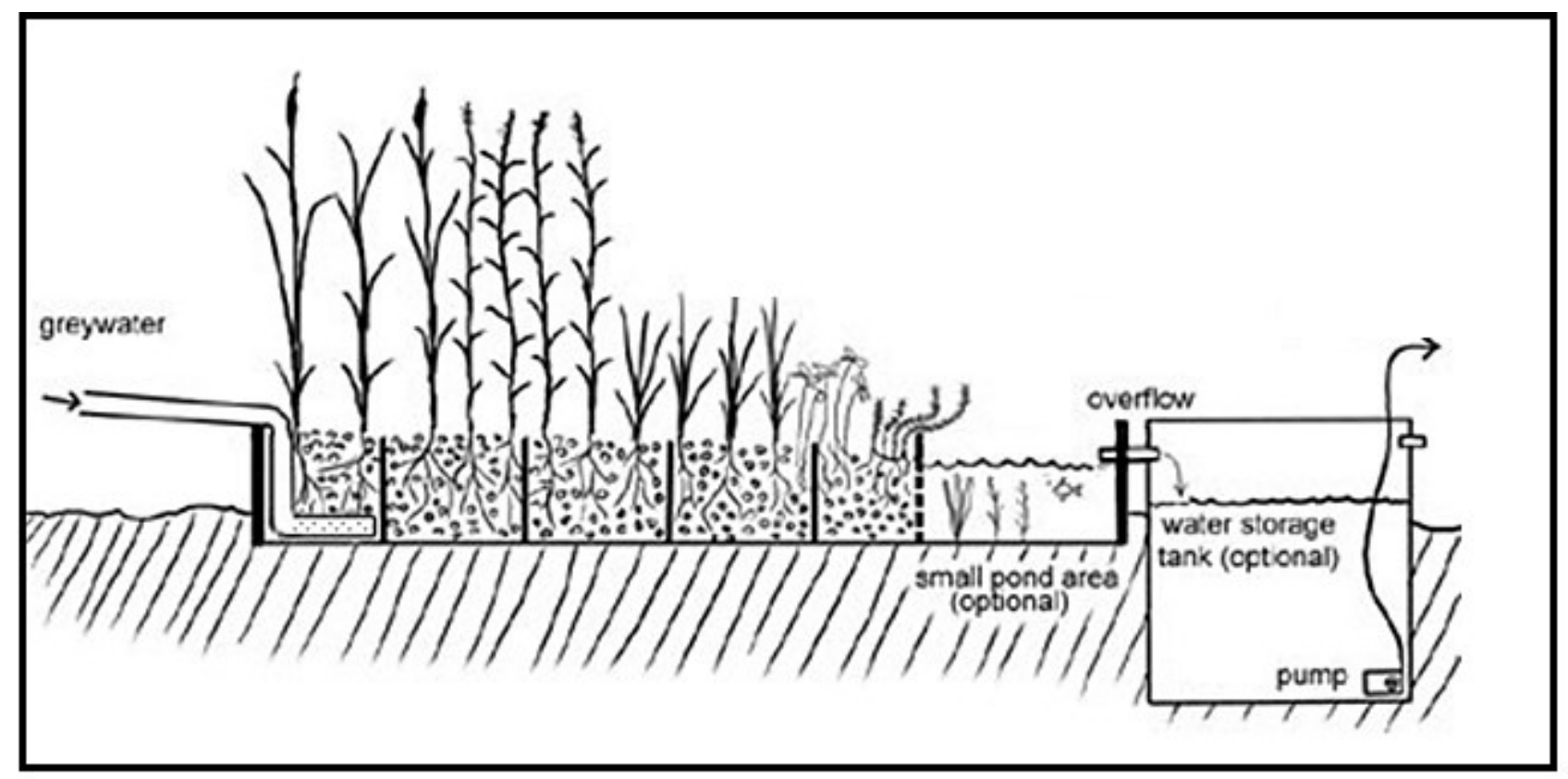

Fig. 1. Simplest schematic flowdiagram of constructed wetland.

Constructed wetlands are wastewater treatment systems composed of one or more treatment cells in a built and partially controlled environment designed and constructed to provide wastewater treatment. While constructed wetlands have been used to treat many types of wastewater at various levels of treatment, the constructed wetlands described in this manual provide secondary treatment to municipal wastewater (Langergraber, 2005). These 
are treatment systems that receive primary effluent and treat it to secondary effluent standards and better, in contrast to enhancement systems or polishing wetlands, which receive secondary effluent and treat it further prior to discharge to the environment.

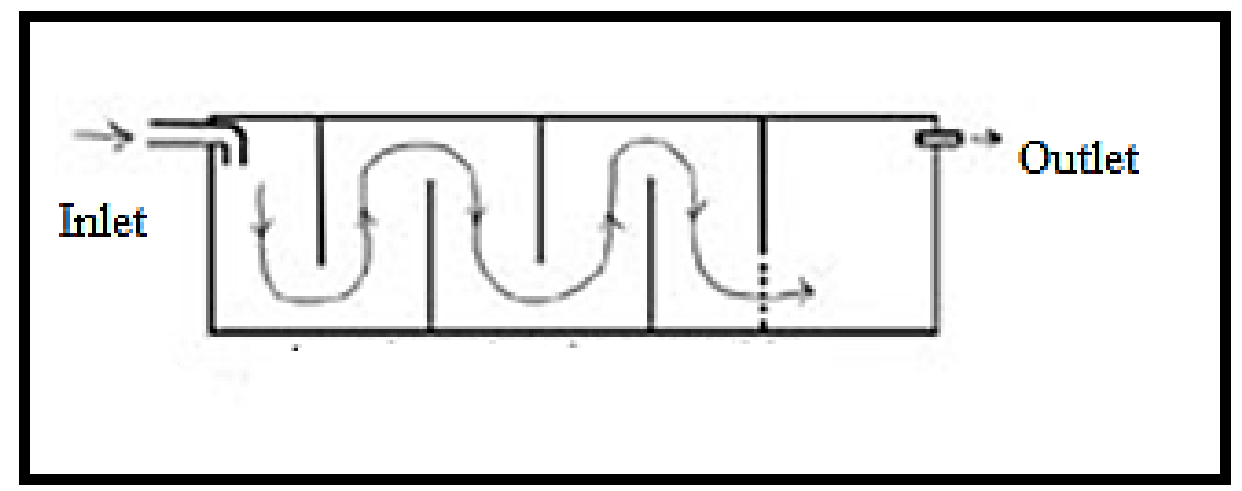

Fig. 2. Top view of the constructed wetland.

Free water surface (FWS) constructed wetlands closely resemble natural wetlands in appearance and function, with a combination of open-water areas, emergent vegetation, varying water depths, and other typical wetland features (Wang et al., 2004). Fig. 2 illustrates the main components of a FWS constructed wetland. A typical FWS constructed wetland consists of several components that may be modified among various applications but retain essentially the same features. These components include berms to enclose the treatment cells, inlet structures that regulate and distribute influent wastewater evenly for optimum treatment, various combinations of open-water areas and fully vegetated surface areas, and outlet structures that complement the even distribution provided by inlet structures and allow adjustment of water levels within the treatment cell. Shape, size, and complexity of design often are functions of site characteristics rather than preconceived design criteria.

\subsection{Analytical}

The absorbance measurements were recorded on a Du-6, UV-VIS spectrophotometer. The concentration of metal ion was determined by gas chromatography (model Hewlett Packard, 5890A).

\section{RESULT AND DISCUSSION}

\section{1. Effect of retention time}

To determine the effect of retention time on the reduction of different heavy metal was shown in Fig. 3. It was observed that the maximum $\mathrm{Cr} 51 \%$, Ni $47 \%$, Fe $45 \%$ and $\mathrm{Hg} 43 \%$ at $9^{\text {th }}$ days of treatment after that on 10 day it become almost constant. The treatment efficiency was increase from 1 day to 8 day the $\mathrm{Cr} 25,28,33,37,42,48,49 \%$, Ni 20.1, 23.7, 27, 31, 39, 43, 45 \%, Fe 22.5, 26, 31, 34, 37, 40, $43 \%$ and $\mathrm{Hg} 21,25,28,32,36,39,41 \%$.

The flow rate was maintained at $70 \mathrm{~cm}^{3} / \mathrm{min}$. The hydraulic residence time (HRT) in the wetland can be calculated with Equation (Carleton and Grizzard, 2011)

$$
\mathrm{T}=\mathrm{LWyn} / \mathrm{Q}
$$


where $\mathrm{T}-$ is the wetland HRT (day);

$L$ - is the length of wetland cell (m);

$W$ - is the width of wetland cell (m);

$y$ - is the depth of water in the wetland cell (1.5 feet in this study);

$n$ - is the porosity, or the space available for water to flow through the wetland (typically $0.75)$;

$Q$ - is the average flow through the wetland $\left(\mathrm{m}^{3} / \mathrm{d}\right)$.

Average flow $(\mathrm{Q})$ is the arithmetic average between the inflow and the outflow. A conservative design might assume no seepage and adopt reasonable estimates for ET losses and rainfall gains from local records for each month of concern. This requires a preliminary assumption regarding the surface area of the wetland so the volume of water lost or added can be calculated. It is usually reasonable for a preliminary design estimate to assume that outflow equals inflow (Baker and Richards, 2002). Based on this assumption, the results show that the retention time in the designed wetland is 9 days.

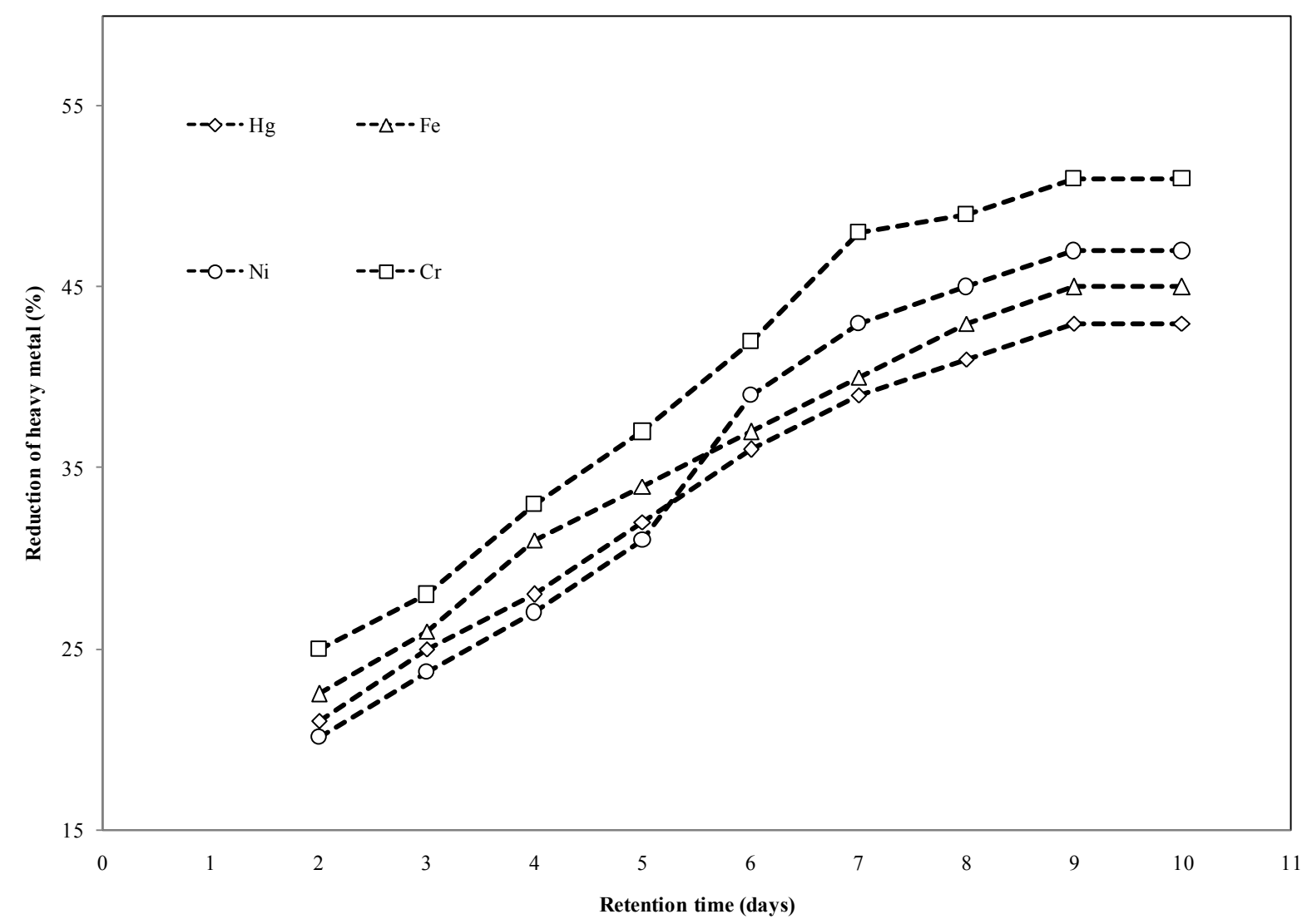

Fig. 3. Effect of retention time on heavy metal reduction.

\section{2. Effect of flow rate}

To determine the effect of flow rate on reduction of heavy metal was carried out at $9^{\text {th }}$ day with different flow rate which is shown in Fig. 4. With increase of flow rate the reduction was alos increase upto $8080 \mathrm{~cm}^{3} / \mathrm{min}$ than decreased. 
The maximum Cr $54 \%$, Ni $49 \%$, Fe $46 \%$ and $\mathrm{Hg} 43 \%$ was observed at $80 \mathrm{~cm}^{3} / \mathrm{min}$ flow rate. After increase the flow rate 90 and $10 \mathrm{~cm}^{3} / \mathrm{min}$, the reduction efficiency $\mathrm{Cr} 40,37$ $\%$, Ni 44, $41 \%, \mathrm{Fe} \mathrm{46,} 44 \%$ and $\mathrm{Hg} 51,47 \%$ respectively.

The decrease and increase in the pollution parameters is attributing to absorbance of organic and inorganic compound by the root of plant (Tao et al., 2006).

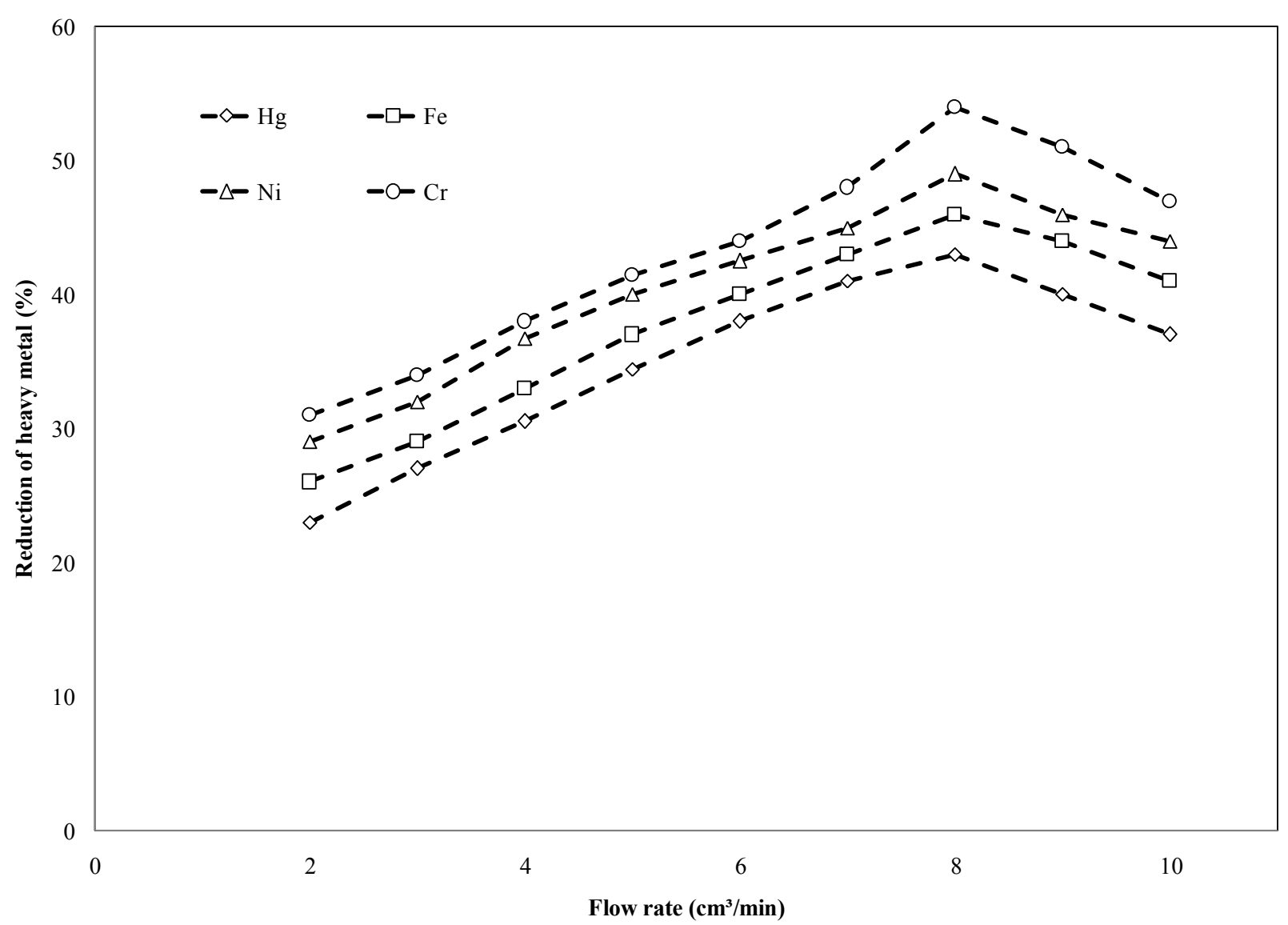

Fig. 4. Effect of flow rate on heavy metal reduction.

\section{3. X-ray diffraction study}

To examine the reduction of heavy metal the x-ray was carried out before treatment and treatment sample, which shown in Fig. 5.

It was found that there is high percentage of $\mathrm{Cr}, \mathrm{Ni}, \mathrm{Fe}$ and $\mathrm{Hg}$ is present in the waste water. After treatment it observed that the percentage of heavy metal was reduced up to permissible limit. 


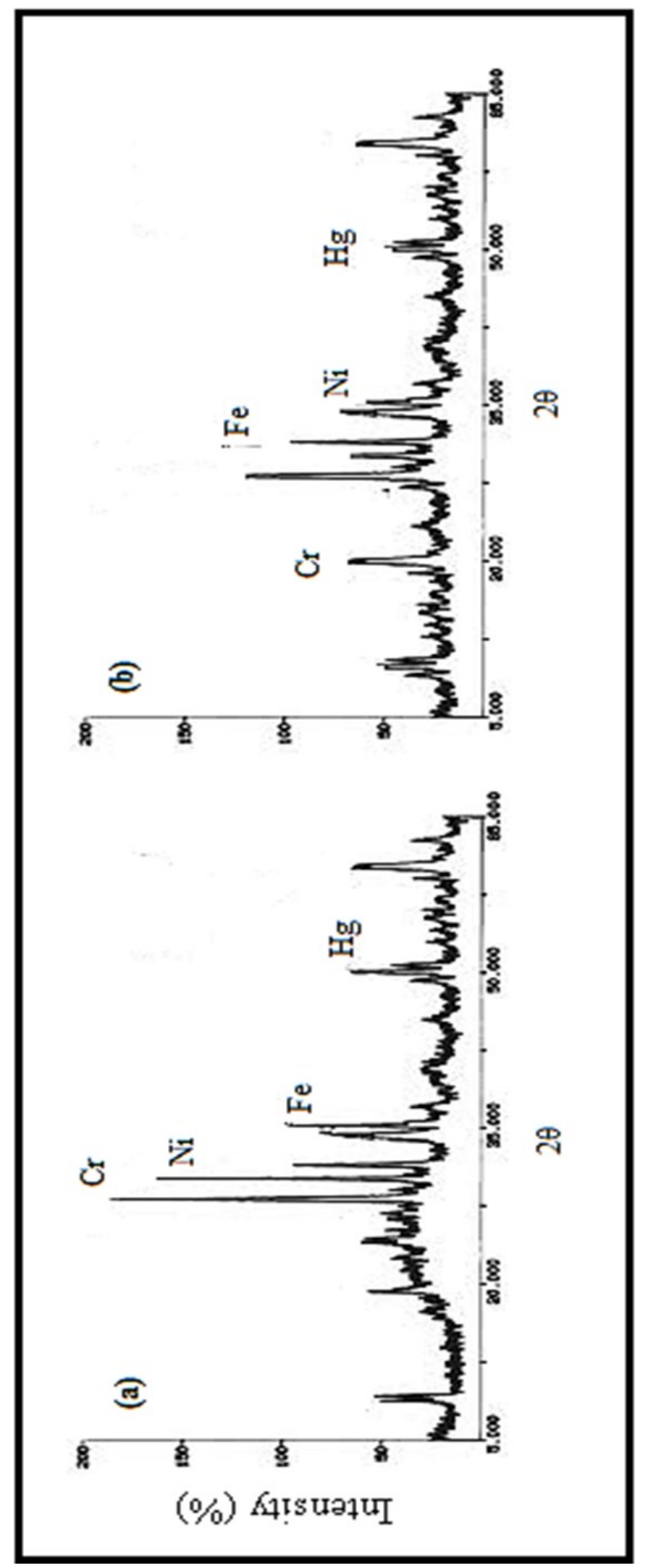

Fig. 5. X-ray diffraction study (a) before treatment (b) after treatment of heavy metal reduction. 


\section{CONCLUSION}

Water reclamation and reuse as a sustainable strategy in water management has been attractive to communities in the intermountain waste, due to the increasing demands placed on freshwater resources driven by population growth and climate change. Constructed wetlands have a great potential for reduction of heavy metal containing wastewater treatment. It has been reduced $\mathrm{Hg} 43 \%, \mathrm{Fe} 46 \%$, Ni $49 \%$, and $\mathrm{Cr} 54 \%$ with careful design and planning, they can treat wastewater with highest possible treatment levels. The cost for design, construction and implementation can be considerably lowered compared to other conventional wastewater treatment technologies. They provide a wide range of benefits in wastewater treatment and represent economic benefits in terms of energy consumption as well as providing opportunities for environmental awareness. They should be investigated and given a chance for use as an alternative technology in wastewater treatment by local municipalities and industries.

\section{Reference}

[1] Allen W.C., Hook P.B., Beiderman J.A., Stein O.R. (2012). Temperature and wetland plant species effects on wastewater treatment and root zone oxidation. Journal of Environmental Quality, 31: 1010-1016.

[2] Bailey L.D. (1976). Effects of temperature and root on denitrification in a soil. Canadian Journal of Soil Science, 56: 79-87.

[3] Baker D.B., Richards R.P. (2002). Phosphorus budgets and riverine phosphorus expert in northwestern Ohio watersheds. Journal of Environmental Quality, 31(1): 96-108.

[4] Baker L.A. (2008). Design consideration and applications for wetland treatment of highnitrate waters. Water Science and Technology, 38(1): 389-395.

[5] Carleton J.N., Grizzard T.J., Godrej A.N., Post H.E. (2011). Factors affecting the performance of stormwater treatment wetlands. Water Research, 35(6): 1552-1562.

[6] Carvalho K.M., Martin D.F. (2011). Removal of aqueous selenium by four aquatic plants. Journal of Aquatic Plant Management, 39: 33-36.

[7] Eriksson P.G. (2011). Interaction effects of flow velocity and oxygen metabolism on nitrification and denitrification in biofilms on submersed macrophytes. Biogeochemistry, 55: 29-44.

[8] Fennessy M.S., Brueske C.C., Mitsch W.J. (2002). Sediment deposition patterns in restored freshwater wetlands using sediment traps. Ecological Engineering, 3(4): 409-428.

[9] Hao X., van Loosdrecht M.C.M. (2004). Model-based evaluation of COD influence on a partial nitrification-Anammox biofilm (CANON) process. Water Science and Technology, 49(11-12): 83-90.

[10] Langergraber G. (2005). The role of plant uptake on the removal of organic matter and nutrients in subsurface flow constructed wetlands: a simulation study. Water Science and Technology, 51(9): 213-223. 
[11] Malmaeus J.M., Hakanson L. (2003). A dynamic model to predict suspended particulate matter in lakes. Ecological Modelling, 167(3): 247-262.

[12] Rasit N.B. (2006). Landfill leachate treatment using subsurface flow constructed wetlands enhanced with magnetic fields. M.S. Thesis, Malaysian University of Technology (Terengganu Darul Iman, Malaysia).

[13] Salih F.M. (2013). Formulation of a mathematical model to predict solar water disinfection. Water Research, 37(16): 3921-3927.

[14] Smith E., Gordon R., Madani A., Stratton G. (2005). Cold climate hydrological flow characteristics of constructed wetlands. Canadian Biosystems Engineering, 47: 1.1-1.7.

[15] Tao W., Hall K.J., Duff S.J.B. (2006). Heterotropic bacterial activities and treatment performance of surface flow constructed wetlands receiving wood waste leachate. Water Environment Research, 78(7): 671-679.

[16] Thullen J.S., Sartoris J.J., Nelson S.M. (2005). Managing vegetation in surface-flow wastewater-treatment wetlands for optimal treatment performance. Ecological Engineering, 25(5): 583-593.

[17] Vymazal J. (2005). Horizontal sub-surface flow and hybrid constructed wetland systems for wastewater treatment. Ecological Engineering, 25(2005): 478-490.

[18] Wang G.-P., Liu J.-S., Tang J. (2004). The long-term nutrient accumulation with respect to anthropogenic impacts in sediments from two freshwater marshes (Xiamghai Wetlands, Northeast China). Water Research, 38(30): 4463-4474.

[19] Zachritz W.H., Lundie L.L., Wang H. (2006). Benzoic acid degradation by small, pilotscale artificial wetlands filter. Ecological Engineering, 7(2): 105-116.

[20] Stottmeister U, Wießner A, Kuschk P, Kappelmeyer U (2003). Effects of plants and microorganisms in constructed wetlands for wastewater treatment. Biotechnol. Adv., 22: 93-117.

[21] Romero SE, Nunez LJ, Negrete M, Rios JEA, Hadad HR, Maine MA (2011). Hg, Cu, $\mathrm{Cd}$, and $\mathrm{Zn}$ Accumulation in Macrophytes growing in tropical wetlands. Water Air Soil Pollut., 216: 361-373.

[22] Sheoran AS, Sheoran V (2006). Heavy metal removal mechanism of acid mine drainage in wetlands: A critical review. J. Miner. Eng., 19:105-116.

[23] Karim MR, Manshadi FD, Karpiscak MM, Gerba CP (2004). The persistence and removal of enteric pathogens in constructed wetlands. J. Water Res., 38: 1831-1837. 